\title{
Future runoff projections for Australia and science challenges in producing next generation projections
}

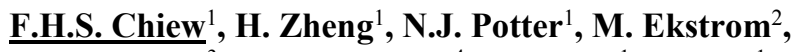 \\ M.R. Grose ${ }^{3}$, D.G.C. Kirono ${ }^{4}$, L. Zhang ${ }^{1}$, J. Vaze $^{1}$ \\ ${ }^{1}$ CSIRO Land and Water, Canberra \\ ${ }^{2}$ School of Earth and Ocean Sciences, Cardiff University, United Kingdom \\ ${ }^{3}$ CSIRO Oceans and Atmosphere, Hobart \\ ${ }^{4}$ CSIRO Oceans and Atmosphere, Melbourne \\ Email:francis.chiew@csiro.au
}

\begin{abstract}
This paper presents future runoff projections across Australia, modelled using climate change projections from 42 CMIP5 global climate models (GCMs) used in the most recent Intergovernmental Panel on Climate Change Fifth Assessment Report (IPCC AR5). The empirical delta scaling method is used to scale the observed historical climate data, informed by the change signal in the GCM (for 2046-2075 relative to 1976-2005 for RCP8.5), to reflect a future climate series. The historical and future runoffs are simulated using a daily hydrological model at $0.05^{\circ}$ grid cells, using parameter values from the geographically nearest calibration catchment (the model is calibrated against streamflow data from more than 700 catchments).
\end{abstract}

The plots in Figure 1 show the median and $10^{\text {th }}$ to $90^{\text {th }}$ percentile range of projections for mean summer, winter and annual runoffs. The median projection for Northern Australia is about 5\% reduction in mean annual runoff, with a $10^{\text {th }}$ to $90^{\text {th }}$ percentile uncertainty range of $-40 \%$ to $+30 \%$. The median projection for eastern Australia is about $15 \%$ reduction in mean annual runoff with an uncertainty range of $-40 \%$ to $+20 \%$. There is stronger agreement in the projections for declining runoff in the far south-west and far south-east where the large majority of GCMs project a drier future winter when most of the runoff in these regions occur. In the far southwest, the median projection is a decline of mean annual runoff of $50 \%$ (with an extreme dry projection of $-70 \%$ ), and in the far south-east, the median projection is a decline of mean annual runoff of $20 \%$ (with an extreme dry projection of $-40 \%$ ).

The paper also discusses the limitations, science challenges and opportunities in producing the next generation hydroclimate projections.

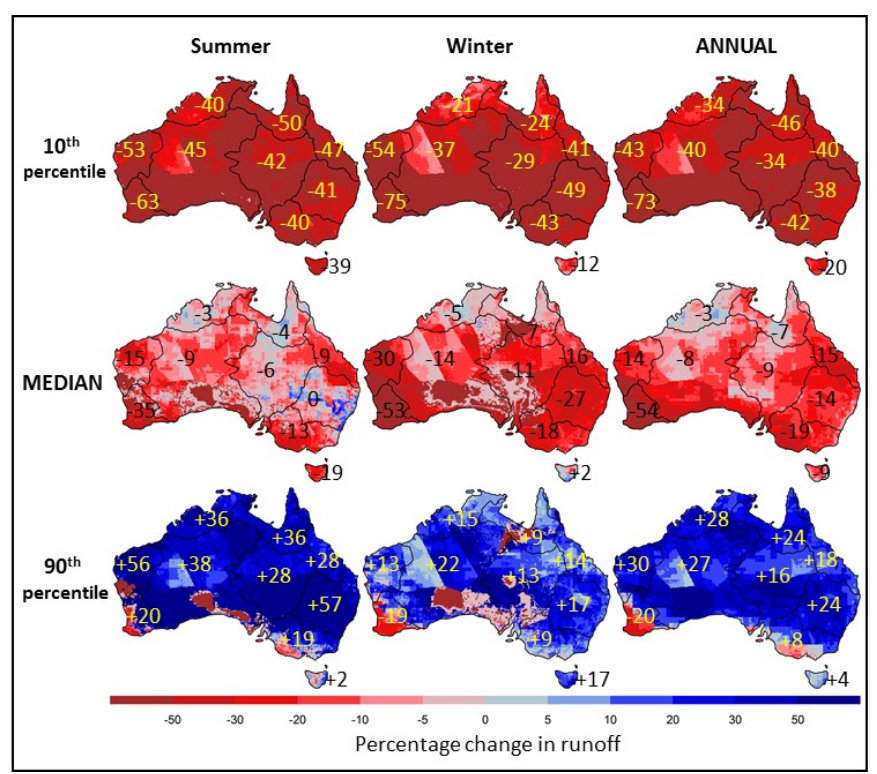

Figure 1. Projected percentage change in mean annual, summer (Dec-Jan-Feb) and winter (Jun-Jul-Aug) runoff (median and the $10^{\text {th }}$ and $90^{\text {th }}$ percentile values from hydrological modelling informed by climate change projections from the 42 CMIP5 GCMs) for RCP8.5 for 2046-2075 relative to 1976-2005.

Keywords: Climate change, runoff, projections, CMIP5 GCMs, Australia 


\section{INTRODUCTION}

This paper presents future runoff projections across Australia, simulated using a hydrological model informed by future climate projections from 42 CMIP5 global climate models. These runoff projections complement the national climate projections for Australia's NRM regions (CSIRO and Bureau of Meteorology 2015, http://www.climatechangeinaustralia.gov.au). The paper also discusses the limitations, science challenges and opportunities in producing the next generation hydroclimate projections.

\section{MODELLING CLIMATE CHANGE IMPACT ON RUNOFF}

The historical and future runoffs are simulated using the GR4J daily conceptual rainfall-runoff model (Perrin et al. 2003) for $0.05^{\circ}$ grid cells across Australia. The GR4J model is calibrated against observed streamflow data from more than 700 catchments (Figure 2). Runoff for each grid cell is modelled using parameter values from the geographically nearest calibration catchment. Runoff is modelled for 1976-2005 (baseline period) using daily rainfall and PET as the input data. The source of the daily rainfall data is the SILO gridded dataset (http://data.qld.gov.au/en/dataset/siloclimate-database, Jeffrey et al. 2001). Potential evapotranspiration is calculated from the SILO climate surface using Morton's wet environment or areal PET algorithms (Morton 1983, Chiew and McMahon 1991).

The future runoff is modelled using future rainfall and PET data obtained by empirically scaling the baseline (1976-2005) historical climate data informed by the change signal from global climate models (GCMs). Empirical scaling factors for each of the four seasons are first used to scale the data (seasonal scaling factor), followed by another rescaling to ensure that the future climate series reflects the GCM change signal at the annual level (annual scaling factor). Therefore, the future climate sequence is the same as the historical climate sequence, and all the daily rainfall and PET in each season are scaled by the same seasonal scaling factor. The choice of empirical scaling method can affect the modelling results, particularly where there are significant differences in the change signal in different parts of the rainfall distribution (e.g. increases in extreme rainfall intensity), and for extreme low and high runoff characteristics (Mpelasoka \& Chiew 2009, Chiew et al. 2009b).

The results presented here are for a change signal for 2046-2075 relative to 1976-2005 for RCP8.5. The RCP8.5 represents the highest representative greenhouse gas concentration pathway defined in IPCC AR5 (Intergovernmental Panel on Climate Change Fifth Assessment Report, IPCC 2014). Projections for different RCPs and time periods have also been simulated, but are not presented here. The projected changes will be smaller for the nearer term and bigger further into the future. The projected changes will be smaller for lower RCPs.

All ensemble runs from the $42 \mathrm{GCMs}$ available on 15 March 2013 (the same date as adopted by IPCC AR5) in the CMIP5 database (http://cmippcmdi.llnl.gov/cmip5/) are used. The GCMs in CMIP5 (Coupled Model Intercomparison Project) come from more than 30 modelling groups across the world.

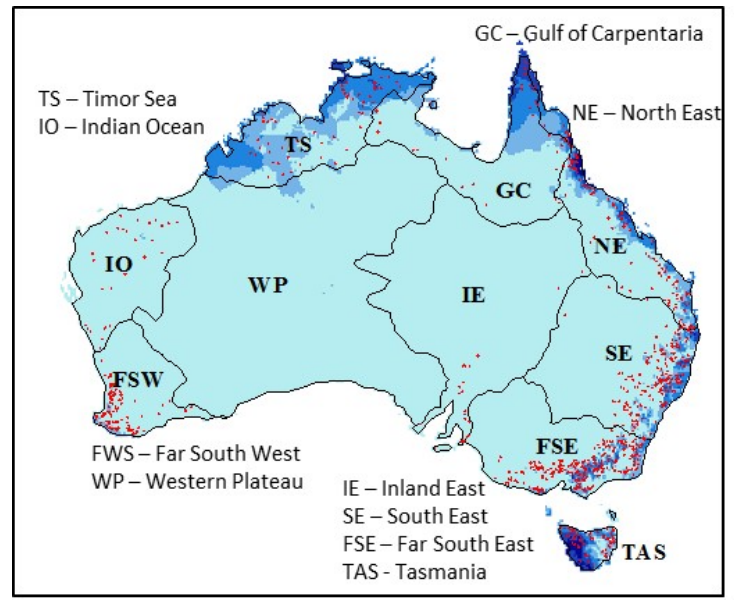

Figure 2. Regions across Australia and locations of gauging stations with observed streamflow data used to calibrate the hydrological model (background shows the spatial runoff distribution across Australia).

\section{PROJECTIONS OF FUTURE CLIMATE AND RUNOFF}

The plots in Figures 3 and 4 show the range of projected changes in future rainfall and PET respectively across Australia. The modelled changes in future runoff are shown in Figure 1 (in the Abstract).

There is considerable uncertainty in the rainfall projections, where the $10^{\text {th }}$ and $90^{\text {th }}$ percentile projections (from the $42 \mathrm{GCMs}$ ) generally differ by up to $50 \%$, and with little agreement in the direction of projected rainfall change in many regions (Figure 3). There is also a considerable range in the rainfall projections in ensemble runs from the same GCM (Figure 5), although this is smaller than the uncertainty across the different GCMs (Figure 3). The rainfall projections from the CMIP5 (IPCC AR5) GCMs for Australia are generally slightly 
wetter than the projections from the previous CMIP3 (IPCC AR4) GCMs (CSIRO and Bureau of Meteorology, 2015).

There is general agreement in the PET projections (Figure 4), with the about $2.5^{\circ} \mathrm{C}$ warming in $2046-2075$ for RCP8.5 (and a small increase in vapour pressure deficit) leading to about $10-15 \%$ increase in PET.

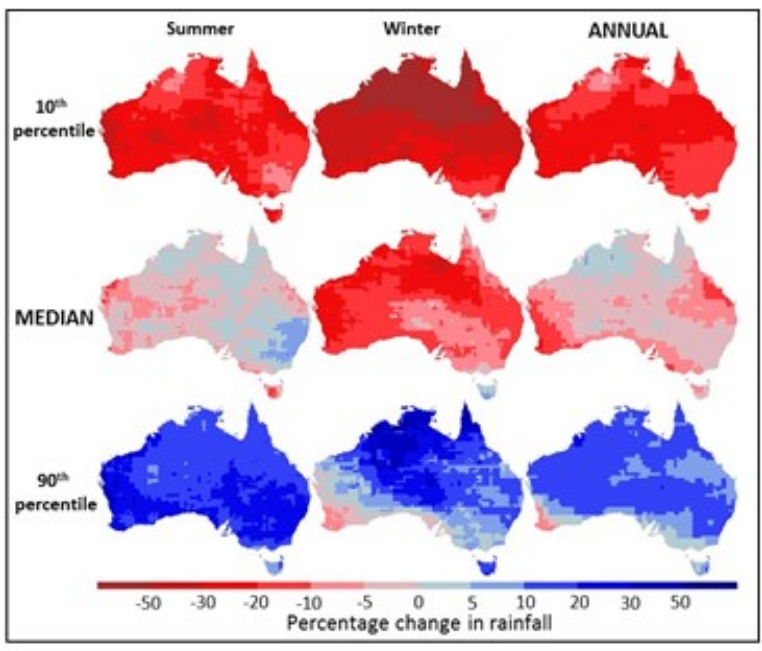

Figure 3. Projected percentage change in mean annual, summer and winter rainfall (median and the $10^{\text {th }}$ and $90^{\text {th }}$ percentile values from the $42 \mathrm{GCMs}$ ) for RCP8.5 for 2046-2075 relative to 1976-2005.

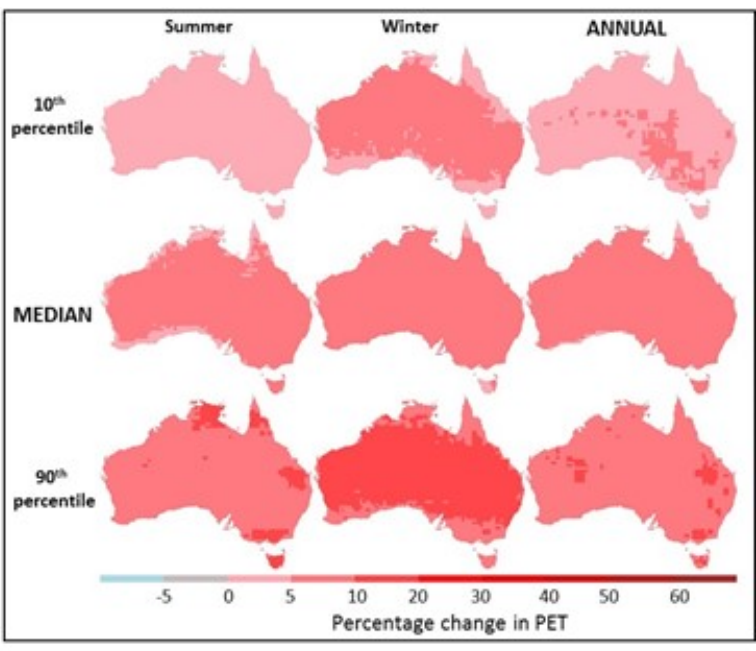

Figure 4. Projected percentage change in mean annual, summer and winter PET (median and the $10^{\text {th }}$ and $90^{\text {th }}$ percentile values from the $42 \mathrm{GCMs}$ ) for RCP8.5 for 2046-2075 relative to $1976-2005$.

The runoff projections (Figure 1) largely reflect the projected change in the rainfall. The percentage change in runoff is generally two to three times larger than the percentage change in rainfall (Chiew 2006), enhanced (where rainfall decrease is projected) or moderated (where rainfall increase is projected) by the runoff reduction from higher PET. The median projection for Northern Australia is about 5\% reduction in mean annual runoff by $2046-2075$ for RCP8.5, with a $10^{\text {th }}$ to $90^{\text {th }}$ percentile uncertainty range of $-40 \%$ to $+30 \%$. The median projection for eastern Australia is about $15 \%$ reduction in mean annual runoff with an uncertainty range of $-40 \%$ to $+20 \%$. There is stronger agreement in the projections for declining runoff in the far south-west and far south-east where the large majority of GCMs project a drier future winter when most of the runoff in these regions occur (Figure 6). The projection of declining winter rainfall is also supported by recent trends in the observations and explanation of change in the global scale circulation under warmer conditions causing a poleward shift in rainfall bearing weather systems in far southern Australia (Hope et al. 2017, Post et al. 2014, CSIRO 2012). In the far south-west, the median projection is a decline of mean annual runoff of $50 \%$ (with an extreme dry projection of $-70 \%$ ), and in the far south-east, the median projection is a decline of mean annual runoff of $20 \%$ (with an extreme dry projection of $-40 \%$ ).

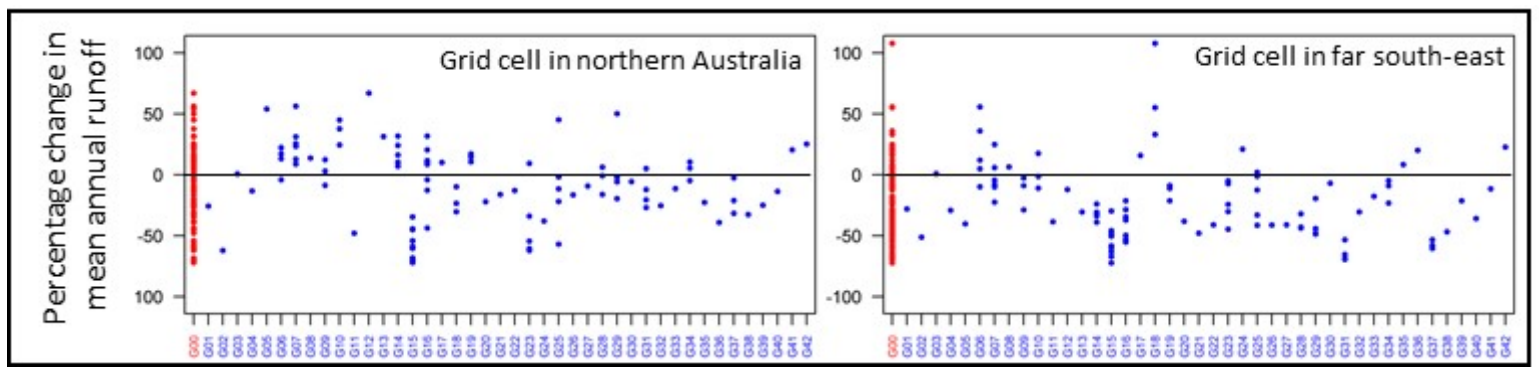

Figure 5. Percentage change in future mean annual runoff modelled by hydrological model informed by future climate projections from all ensemble runs from the 42 GCMs for RCP8.5 for 2046-2075 relative to 1976-2005 for a grid cell in northern Australia and a grid cell in far south-east.

The first column (G00 in red) shows results from the first run of each of the $42 \mathrm{GCMs}$ (as presented in Figure 1) and the other columns (G01 to G42) show results for ensemble runs for each of the 42 GCMs. 


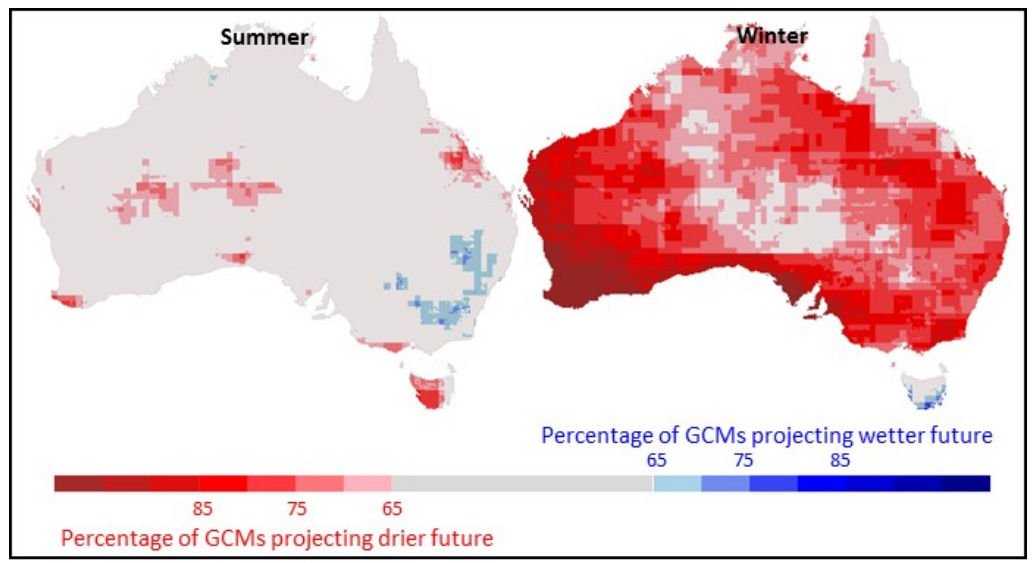

Figure 6. Percentage of GCMs (from the 42 CMIP5 GCMs) projecting rainfall increase and rainfall decrease across Australia.

\section{LIMITATIONS, SCIENCE CHALLENGES AND OPPORTUNITIES}

\subsection{Reducing uncertainty in rainfall projections from sub-sampling projections data?}

The largest uncertainty in the runoff projections come from the uncertainty in the future rainfall projections. Numerous studies have explored reducing the uncertainty by putting more weight on, or using only, the GCMs that best reproduce the current climatology. Although some studies show that this approach can reduce the range in the projections in some regions, the majority of studies show little correlation between the "better" GCMs and the future rainfall projections, and therefore using only the better GCMs tend to provide similar projections and uncertainty in the projections. The GCMs may also perform differently under different evaluation criteria (e.g. ability to reproduce the observed rainfall over a region versus the whole of Australia, ability to reproduce large-scale atmospheric and oceanic indices or drivers of rainfall (like ENSO), and ability to reproduce the relationship between the large scale drivers and regional rainfall), making the choice of GCMs difficult. For these reasons, many studies have chosen to use all available projection data sources to represent the full range of uncertainty in the future rainfall projections. Selected Australian studies include CSIRO and Bureau of Meteorology (2015), Chiew et al. (2009a), Smith \& Chandler (2009) and Suppiah et al. (2007).

Recent studies are exploring constraining the future rainfall projections to a more plausible range (known as 'emergent constraints') by examining the physical drivers behind the modelled rainfall change, or quantifying the relationship between bias (the ability of the model to reproduce observations) and projected change to elucidate if the bias affects the projections. For example, Brown et al. (2016) showed that summer rainfall change in northern Australia may be constrained to the wetter projections, and Grose et al. (2017) showed that winter rainfall in southern Australia can be constrained to the drier projections.

\subsection{More robust rainfall projections from downscaling?}

Downscaling is the process of translating or modelling the coarse spatial resolution $(>100 \mathrm{~km})$ outputs from GCMs to catchment scale rainfall that is required for impact-adaptation-vulnerability studies and hydrological modelling. The empirical scaling or change factor method used here is one form of downscaling, where the observed historical rainfall time series is scaled by the change signal in the GCM. In statistical downscaling, a relationship between GCM atmospheric variables and observed rainfall is developed, and this relationship is then used to derive future rainfall from future GCM variables. In dynamic downscaling, a regional climate model is used to model the physical atmospheric and land surface processes at smaller spatial scale informed or constrained by the large scale GCM. The statistical and dynamic downscaling methods, unlike the change factor method, produce new information in the simulation of climate processes and therefore have the potential to provide more robust rainfall projections, particularly in regions influenced by topography and coastline. Overview and comparison of downscaling methods for hydrological modelling can be found in Ekstrom et al. (2015), Frost et al. (2011), Chiew et al. (2010) and Fowler et al. (2007).

Downscaling products are continually being developed for Australia, for research purposes and for climate projection projects for state water and environmental agencies. Statistical downscaling datasets include the Bureau of Meteorology analogue Statistical Downscaling Model (SDM) dataset for Australia (Timbal et al. 2009, Teng et al. 2012a), and the Nonhomogeneous Hidden Markov Model (NHMM) statistical downscaled dataset for South Australia (Charles \& Fu 2014, Fu et al. 2013). Dynamic downscaling datasets include the 
Weather Research and Forecasting (WRF) dataset for New South Wales and south-eastern Australia (Evans et al. 2014) and the Conformal Cubic Atmospheric Model (CCAM) datasets centred on Tasmania, Victoria and Queensland (McGregor \& Dix, 2008). Links to these datasets can be found in CSIRO and Bureau of Meteorology (2015).

The downscaled rainfall data looks more realistic than the coarse resolution GCM data. For example, data from the empirical change factor method is exactly the same as the observed historical data, and statistical downscaling models are 'calibrated' to reproduce the observed data. However, rainfall from dynamic downscaling models needs to be 'bias corrected' to make its distribution and characteristics more similar to the observed rainfall for hydrological modelling (Teng et al. 2015, Argueso et al. 2013, Bennett et al. 2013).

Downscaling can also produce a climate change signal that is more physically plausible than the host GCM, in fact this is one of the main reasons for downscaling. However, this is difficult to ascertain as downscaling models (particularly dynamic downscaling) also introduce model-specific representations of processes. This challenge is compounded when projections from different downscaling models are different, or when downscaled projections differ from the host GCMs providing the boundary conditions. For example, Ekstrom et al. (2016), Hope et al. (2017) and Potter et al. (2017) showed that for Victoria, the SDM projections are drier, WRF projections are slightly wetter, and CCAM projections are considerably wetter than the range of CMIP5 GCM projections (Figure 7). Grose et al. (2015a) also showed similar disagreements in future climate projections from different sources for New South Wales.

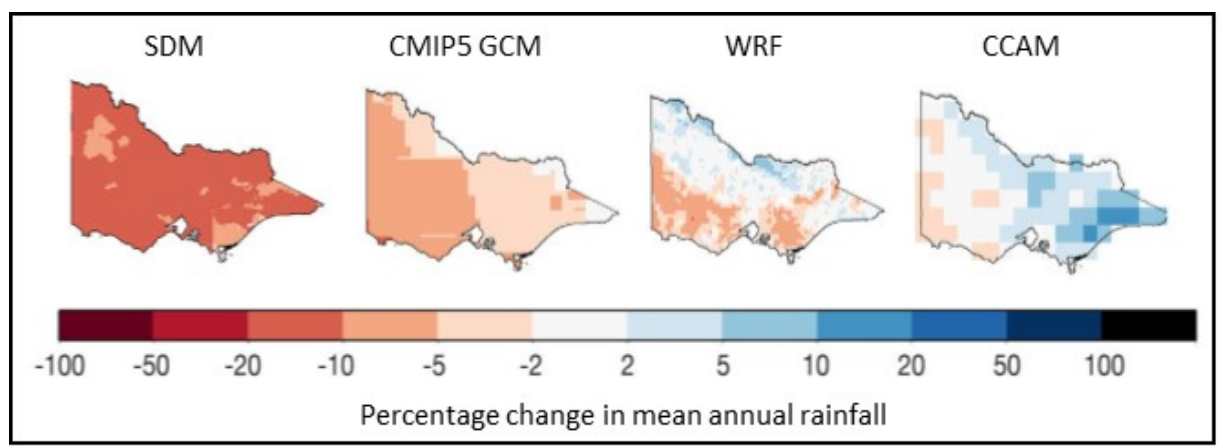

Figure 7. Ensemble median change in future rainfall in Victoria by around 2065 projected by the 42 CMIP5 GCMs, analogue statistical downscaling model (SDM), and WRF and CCAM dynamic downscaling models (adapted from Hope et al. 2017 and Potter et al. 2017).

Therefore, given the current state of science and data availability, it is probably best to use the broad range of projections from all available model sources (GCMs and downscaled datasets) to avoid over confidence in the projections and lessen the chance of maladaptation (CSIRO and Bureau of Meteorology 2015, Ekstrom et al. 2016). Research efforts to enhance confidence in downscaled products include better understanding of the climate dynamics and land surface processes at higher resolution, reducing the downscaled rainfall bias pattern, developing robust fit-for-purpose bias correction methods to produce catchment scale rainfall characteristics that drive runoff, and explaining the change signal in the downscaled data relative to the host GCM. CSIRO and Bureau of Meteorology (2015), Ekstrom et al. (2016) and Grose et al. (2015b) provide excellent discussions of the above issues and implications on choosing projections data for impact and adaptation studies.

\subsection{Extrapolating hydrological models to predict the future}

The hydrological modelling approach used here considers only the changes in future runoff from changes in the climate inputs (rainfall and PET). Numerous studies have shown that most adequately calibrated hydrological models, as well as universal energy and water balance equations like the Budyko framework (Budyko 1974) and $\mathrm{Fu}$ equation (Fu 1981), give similar future mean runoff projections when informed by the same future climate change signal. That is, the uncertainty in the future rainfall projections is much larger than the uncertainty in the choice of hydrological models (Teng et al. 2012b, Chiew et al. 2009).

However, because of the different process conceptualisations, hydrological models can differ considerably when used to predict changes in hydrological variables beyond the averages, like high flows, overbank flows, low flow characteristics and connectivity, multi-year storage reliability, and groundwater recharge. Therefore, hydrological impact studies must properly consider the choice of hydrological model and parameterisation method for the specific modelling objectives as well as choice of projections that can meaningfully reflect the changes in rainfall characteristics that influence the hydrological variable. Modelling with the AWRA 
landscape hydrological model (Vaze et al. 2013, http:/www.bom.gov.au/water/landscape) may provide broad consistency in the interpretation of projections of hydrological fluxes and stores including soil moisture, because AWRA explicitly represents soil and vegetation characteristics influencing the hydrology and attempts to consistently simulate the different hydrological fluxes and stores. However, there is no one single model that can be used for all applications, and detailed impact studies must consider hydrological models and climate projections tailored to the application.

The hydrological models are potentially limited when extrapolated to predict a future that can be considerably different from the past. Many studies have shown the inability of hydrological models to simulate hydrologic regimes that are considerably different to regimes that was used to calibrate the models. This was particularly evident in the drying in the far south-west and the Millennium drought in south-eastern Australia, which exposed changes in rainfall-runoff relationships and dominant hydrologic processes in long dry spells (Chiew et al. 2014, Coron et al. 2012, Hughes et al. 2012, Vaze et al. 2010, Potter et al. 2010, Saft et al. 2016). The understanding of hydrologic non-stationarity and using new knowledge to improve and adapt hydrological models to predict the future is an important area of ongoing research (Vaze et al. 2015, Montanari et al. 2013, Peel \& Bloschl 2011, Fowler et al. 2016, Milly et al. 2008).

Nevertheless, hydrological models developed and calibrated against long historical record (particularly when the data also includes extreme characteristics like the Millennium drought) should be able to satisfactorily predict near-term runoff over the next 10-20 years. However, further into the future, runoff will be increasingly influenced by higher temperature and ecohydrological (vegetation) processes under higher $\mathrm{CO}_{2}$ (Cheng et al. 2017, Ukkola et al. 2015, Betts et al. 2007). Reliably modelling these is difficult because of the complex interactions and feedbacks between the many processes in a warmer and higher $\mathrm{CO}_{2}$ environment not seen in the past. Future improvements will come from improved scientific understanding and process representations in landscape hydrological models (like AWRA) and earth system science models (like CABLE, Raupach et al. 2013, http://www.cawcr.gov.au/research/cable), as well as pragmatic fit-for-purpose approaches adapting existing conceptual hydrological models to better predict the future (selected examples include model calibration that considers dry-wet spells and range of hydrological variables, improved conceptualisation of surface and groundwater connectivity and dominant hydrological processes in long dry spells, and simple coupling of the carbon and water cycle).

\section{SUMMARY}

This paper presents future runoff projections across Australia, simulated using a hydrological model informed by future climate projections from 42 CMIP5 GCMs. These runoff projections complement the national climate projections for Australia's NRM regions. The paper then discusses the limitations, science challenges and opportunities in producing the next generation hydroclimate projections. Improvements in the projections will come from better understanding of regional climate dynamics, improved global and regional climate modelling in CMIP6, interpretation and combination of projection data sources, and robust hydrological modelling that simulates changes in rainfall-runoff relationship and ecohydrological processes under changed rainfall condition, warmer climate and enhanced $\mathrm{CO}_{2}$. However, there will still be considerable uncertainty in the future projections, and therefore assessment of vulnerability of water resources and related systems and adaptation strategies must consider the full range of plausible future projections.

\section{ACKNOWLEDGEMENTS}

The information in this paper comes from research funded by various sources, including CSIRO strategic research fund, Victorian Climate Initiative, and the Earth Systems and Climate Change Hub of the Australian Government's National Environmental Science Programme.

\section{REFERENCES}

\footnotetext{
Argueso D, Evans JP and Fita L (2013). Precipitation bias correction of very high resolution regional climate models. Hydrology and Earth System Science, 17, 43794388, http://dx.doi.org/10.5194/hess-17-4379-2013.

Bennett JC, Grose MR, Corney SP, White CJ, Holz GK, Katzfey JJ, Post DA and Bindoff NL (2013). Performance of an empirical bias-correction of a high resolution climate dataset. International Journal of Climatology, 34,2189-2204. http://dx.doi.org/10.1002/joc.3830.

Betts RA, Boucher O, Collins M et al. (2007). Projected increase in continental runoff due to plant response to increasing carbon dioxide. Nature, 448, $1037-1041$. Brown JR, Moise AF, Coleman R and Zhang H (2016). Will a warmer world mean a wetter or drier Australian monsoon? Journal of Climate, 29, 4577-4596,
http://dx.doi.org/10.1175/JCLI-D-15-0695.1.

Budyko MI (1974). Climate and life. Academic Press, San Diego.

Charles SP and Fu G (2014). Statistically downscaled projections for South Australia - Task 3, CSIRO final report. Goyder Institute for Water Research Technical Report 15/1, Adelaide, South Australia.

Cheng L, Zhang L, Wang YP, Canadell JG, Chiew FHS, Beringer J, Li L, Miralles DG, Piao S and Zhang Y (2017). Recent increases in terrestrial carbon uptake at little cost to the water cycle. Nature Communications, 8, http://dx.doi.org/s41467-017-00114-5.

Chiew FHS (2006). Estimation of rainfall elasticity of streamflow in Australia. Hydrological Sciences Journal, 51, 613-625, http://dx.doi.org/10.1623/hysj.51.4.613.

Chiew FHS and McMahon TA (1991). The applicability of Morton's and Penman's evapotranspiration estimates in rainfall-runoff modelling. Water Resources Bulletin, 27, 611-620, http://dx.doi.org/10.1111/j.1752-1688.1991.tb01462.x.
} 
Chiew FHS, Kirono DGC, Kent DM, Frost AJ, Charles SP, Timbal B, Nguyen KC and Fu G (2010). Comparison of runoff modelled using rainfall from different downscaling methods for historical and future climates. Journal of Hydrology, 387, 10-23, http://dx.doi.org/10.1016/j.jhydrol.2010.03.025.

Chiew FHS, Potter NJ, Vaze J, Petheram C, Zhang L, Teng J and Post DA (2014). Observed hydrologic non-stationarity in far south-eastern Australia: implications and future modelling predictions. Stochastic Environmental Research and Risk Assessment, 28, 3-15, http://dx.doi.org/10.1007/s00477-013-0755-5.

Chiew FHS, Teng J, Vaze J and Kirono DGC (2009a). Influence of global climate model selection on runoff impact assessment. Journal of Hydrology, 379, 172-180, http://dx.doi.org/10.1016/j.jhydrol.2009.10.004.

Chiew FHS, Teng J, Vaze J, Post DA, Perraud J-M, Kirono DGC and Viney NR (2009b). Estimating climate change impact on runoff across south-east Australia: method, results and implications of modelling method. Water Resources Research, 45, W10414, http://dx.doi.org/10.1029/2008WR007338.

Coron L, Andreassian V, Perrin C, Lerat J, Vaze J, Bourqui M and Hendrickz F (2012). Crash testing hydrological models in contrasted climate conditions: an experiment on 216 Australian catchments. Water Resources Research, 48, W05552, http://dx.doi.org/10.1029/2011WR011721.

CSIRO (2012). Climate variability and change in south-eastern Australia: a synthesis of findings from Phase 2 of the South Eastern Australian Climate Initiative (SEACI). CSIRO, Australia, 41 pp, http://www.seaci.org/publications/documents/SEACI-2Reports/SEACI_Phase2_SynthesisReport.pdf.

CSIRO and Bureau of Meteorology (2015). Climate change in Australia information for Australia's natural resources management regions. Technical report, CSIRO and Bureau of Meteorology, https://www.climatechangeinaustralia.gov.au.

Ekstrom M, Grose M, Heady C, Turner S and Teng J (2016). The method of producing climate change datasets impacts the resulting policy guidance and chance of maladaptation. Climate Services, 4, 13-29, http://dx.doi.org/10.1016/j.cliser.2016.09.003

Ekstrom M, Grose MR, Whetton PH (2015). An appraisal of downscaling methods used in climate change research. WIREs Climate Change, http://dx.doi.org/10.1002/wcc.339.

Evans JP, Ji F, Lee C, Smith P, Argueso D and Fita L (2014). Design of a regional climate modelling projection ensemble experiment NARCliM. Geoscience Model Development, 7, 621-629, http://dx.doi.org/10.5194/gmd-7-621-2014

Fowler HJ, Blenkinsop S and Tebaldi C (2007). Linking climate change modelling to impact studies: recent advances in downscaling techniques for hydrological modelling. International Journal of Climatology, 27, 1547-1578, http://dx.doi.org/10.1002/joc. 1556.

Fowler KJ, Peel MC, Western AW, Zhang L and Peterson TJ (2016). Simulating runoff under changing climate conditions: revisiting an apparent deficiency of conceptual rainfall-runoff models. Water Resources Research, 3, 1820-1846, http://dx.doi.org/10.1002/2015WR018068.

Frost AJ, Charles SP, Timbal B, Chiew FHS, Mehotra R, Nguyen KC, Chandler RE, McGregor JL, Fu G, Kirono DGC, Fernandez E and Kent DM (2011). A comparison of multi-site daily rainfall downscaling techniques under Australian conditions. Journal of Hydrology, 408, 1-18,

Fu BP (1981). On the calculation of evaporation from land surface. Science Atmosphere Sinica (Chinese), 5, 23-31.

Fu G, Charles SP, Chiew FHS, Teng J, Zheng H, Frost AJ, Liu W and Kirshner S (2013). Modelling runoff with statistically downscaled daily site, gridded and catchment rainfall series. Journal of Hydrology, 492, 254-265, http://dx.doi.org/10.1016/j.jhydrol.2013.03.041.

Grose MR, Bhend J, Argueso D, Ekstrom M, Dowdy AJ, Hoffman P, Evans JP and Timbal B (2015a). Comparison of various climate change projections of eastern Australian rainfall. Australian Meteorological and Oceanographic Journal, 65, 72-89.

Grose MR, Moise AF, Timbal B, Katzfey, Ekstrom M and Whetton PH (2015b). Climate projections for southern Australia cool season rainfall: insights from a

downscaling comparison. Climate Research, 62, 251-265, http://dx.doi.org/10.3354/cr01276.
Grose MR, Risbey JS, Moise AF, Osbrough S, Heady C, Wilson L and Erwin T (2017). Constraints on southern Australian rainfall change based on atmospheric circulation in CMIP5 simulations. Journal of Climate, 30, 225-242, http://dx.doi.org/10.1175/JCLI-D-16-0142.1.

Hope P, Timbal B, Hendon H, Ekstrom M and Potter N (2017). A synthesis of findings from the Victorian Climate Initiative. Australian Bureau of Meteorology, 56 pp, http://www.water.vic.gov.au/_ data/assets/pdf file/0030/76197/VicCI-25-07-17-MR.pdf.

Hughes JD, Petrone KC, Silberstein R (2012). Drought, groundwater storage and streamflow decline in southwestern Australia. Geophysical Research Letters, 39 , L03408, http://dx.doi.org/10.1029/2011GL050797.

Intergovernmental Panel on Climate Change (2014). Climate change 2014: synthesis report. Contribution of working groups I, II and III to the Fifth Assessment Report of the IPCC, $151 \mathrm{pp}$, http://www.ipcc.ch/report/ar5/syr/.

Jeffrey SJ, Carter JO, Moodie KB and Beswick AR (2001). Using spatial interpolation to construct a comprehensive archive of Australian climate. Environmental Modelling and Software, 16, 309-300, http://dx.doi.org/10.1016/S1364-8152(01)00008-1.

McGregor J and Dix M (2008). An updated description of the conformal-cubic atmospheric model. In: K Hamilton \& W Ohfuchi (Eds), High resolution numerical modelling of the atmosphere and ocean, Springer, New York.

Milly PCD, Betancourt J, Falkenmark M, Hirsch RM, Kundzewicz ZW, Lettenmaier DP and Stouffer RJ (2008). Stationary is dead: whither water management? Science, 319, 573-574, http://dx.doi.org/10.1126/science.1151915.

Montanari A, Young G, Savinije HHG et al. (2015). "Panta-Rhei - Everything Flows": Change in hydrology and society - the IAHS scientific decade $2013-2022$. Hydrological Sciences Journal, 58, 1256-1275, http://dx.doi.org/10.1080/02626667.2013.809088.

Morton FI (1983). Operational estimates of areal evapotranspiration and their significance to the science and practice of hydrology. Journal of Hydrology, 66, 1-76, http://dx.doi.org/10.1016/0022-1694(83)90177-4.

Mpelasoka FS and Chiew FHS (2009). Influence of rainfall scenario construction methods on runoff projections. Journal of Hydrometeorology, 10, 1168-1183, http://dx.doi.org/10.1175/2009JHM1045.1.

Peel MC and Bloschl G (2011). Hydrological modelling in a changing world. Progress In Physical Geography, 35, 249-261, http://dx.doi.org/10.1177/0309133311402550.

Perrin C, Michel C and Andreassian V (2003). Improvement of a parsimonious model for streamflow simulations. Journal of Hydrology, 279, 275-289, http://dx.doi.org/10.1016/S0022-1694(03)00225-7.

Post DA, Timbal B, Chiew FHS, Hendon HH, Nguyen H and Moran R (2014). Decrease in southeastern Australian water availability linked to ongoing Hadley cell expansion. Earth's Future, 2, 231-238, http://dx.doi.org/10.1002/2013EF000194.

Potter NJ, Chiew FHS and Frost AJ (2010). An assessment of the severity of recent reductions in rainfall and runoff in the Murray-Darling Basin. Journal of

Hydrology, 381, 52-64, http://dx.doi.org/10.1016/j.jhydrol.2009.11.025.
Potter NJ, Ekstrom M, Chiew FHS, Zhang L and Fu G (2017). Uncertainty from downscaling global climate model information for hydroclimate projections. In Review.

Potter NJ, Chiew FHS, Zheng H, Ekstrom M and Zhang L (2016). Hydroclimate projections for Victoria at 2040 and 2065. CSIRO, Australia. http://publications.csiro.au/rpr/pub?pid=csiro:EP161427.

Raupach MR, Haverd V and Briggs PR (2013). Sensitivities of the Australian terrestrial water and carbon balances to climate change and variability. Agriculture Forest and Meteorology, 182-183, 277-291, http://dx.doi.org/10.1016/j.agrformet.2013.06.017.

Saft M, Peel MC, Western AW, Perraud JM and Zhang L (2016). Bias in streamflow projections due to climate-induced shifts in catchment response. Geophysical Research Letters, 43, 1574-1581, http://dx.doi.org/10.1002/2015GL067326.

Smith IN and Chandler E (2009). Refining rainfall projections for the Murray-Darling Basin of south-eastern Australia - the effect of sampling model results based on performance. Climatic Change, 102, 377-393, http://dx.doi.org/doi:10.1007/s10584-009-9757-1.

Suppiah R, Hennessy KJ, Whetton PH, McInnes K, Macadam I, Bathols J, Ricketts J and Page CM (2007). Australian climate change projections derived from simulations performed for the IPCC $4^{\text {th }}$ Assessment Report. Australian Meteorological Magazine, 56, 131-152.

Teng J, Chiew FHS, Timbal B, Wang Y, Vaze J and Wang B (2012a). Assessment of an analogue downscaling method for modelling climate change impacts on runoff. Journal of Hydrology, 472-473, 111-125, http://dx.doi.org/10.1016/j.jhydrol.2012.09.024.

Teng J, Potter NJ, Chiew FHS, Zhang L, Wang B, Vaze J, Evans JP (2015). How does bias correction of regional climate precipitation affect modelled runoff?

Hydrology and Earth System Science, 19, 711-728, http://dx.doi.org/10.5194/hess-19-711-2015.
Teng J, Vaze J, Chiew FHS, Wang B and Perraud J-M (2012b). Estimating the relative uncertainties sourced from GCMs and hydrological models in modelling climate change impact on runoff. Journal of Hydrometeorology, 13, 122-139, http://dx.doi.org/10.1175/JHM-D-11-058.1.

Timbal B, Fernandez E and Li Z (2009). Generalisation of a statistical downscaling model to provide local climate change projections for Australia. Environmental Modelling and Software, 24, 341-358, http://dx.doi.org/10.1016/j.envsoft.2008.07.007.

Ukkola AM, Prentice C, Keenan TF, van Dijk AIJM, Viney NR, Myeni RB and Bi J (2015). Reduced streamflow in water-stressed climates consistent with $\mathrm{CO}_{2}$ effects on vegetation. Nature Climate Change, 6, 75-80, http://dx.doi.org/10.1038/nclimate2831.

Vaze J, Chiew FHS, Hughes D and Andreassian V (Editors) (2015). Hydrological Non-Stationarity and Extrapolating Models to Predict the Future. Proceedings of the International Association of Hydrological Sciences (PIAHS), Volume 371, http://www.proc-iahs.net/371/index.html.

Vaze J, Post DA, Chiew FHS, Perraud J-M, Viney N and Teng J (2010). Climate non-stationarity - validity of calibrated rainfall-runoff models for use in climate change studies. Journal of Hydrology, 394, 447-457, http://dx.doi.org/10.1016/j.jhydrol.2010.09.018.

Vaze J, Viney N, Stenson M, Renzullo L, Van Dijk A, Dutta R, et al. (2013). The Australian Water Resource Assessment System (AWRA). Proceedings of the 20 International Congress on Modelling and Simulation (MODSIM 2013), Dec 2013, Adelaide, Australia. 